Acta Veterinaria Hungarica 62 (3), pp. 317-333 (2014)

DOI: 10.1556/AVet 2014.001

First published online 22 March 2014

\title{
EFFECTS OF STEROIDS ON THE MORPHOLOGY AND PROLIFERATION OF CANINE AND EQUINE MESENCHYMAL STEM CELLS OF ADIPOSE ORIGIN - IN VITRO RESEARCH
}

\author{
Krzysztof MARYCZ ${ }^{1}$, Agnieszka ŚMIESZEK ${ }^{1}$, Jakub GRZESIAK ${ }^{1 *}$ and Jakub E. NiCPOŃ ${ }^{2}$ \\ ${ }^{1}$ Electron Microscopy Laboratory, University of Environmental and Life Sciences \\ Wroclaw, Kozuchowska 5b, 51-631 Wroclaw, Poland; ${ }^{2}$ Department of Surgery, \\ Faculty of Veterinary Medicine, Wroclaw University of Environmental and \\ Life Sciences, Wroclaw, Poland
}

(Received 6 March 2013; accepted 2 July 2013)

\begin{abstract}
Disorders of the locomotive system, especially those occurring due to degenerative changes of the joints, are serious problems in daily veterinary medical practice. Steroid injections are the main way of treating these disorders. However, this approach brings usually only temporary effects of pain relief, and may cause many side effects. Alternative therapies focus on regeneration of damaged tissue using adult mesenchymal stem cells (MSCs). Since 2002, the great plasticity and immunomodulatory properties of MSCs isolated from adipose tissue (AdMSCs) have been used successfully in the treatment of degenerative joint diseases (DJD) of both dogs and horses. Possible simultaneous application of steroid therapy and stem cell transplantation could improve the commonly used clinical procedure. In this paper, the influence of the two steroid drugs (betamethasone and methylprednisolone) on AdMSCs was evaluated on the basis of morphology and proliferation rate. Both steroids positively influenced the viability and proliferation state of cells in a concentration of $0.01 \mathrm{mg} / \mathrm{ml}$ and $0.1 \mathrm{mg} / \mathrm{ml}$, respectively. However, the concentration of $1 \mathrm{mg} / \mathrm{ml}$ had a cytotoxic effect. Moreover, the lower dosage of steroid drugs used in the experiment did not affect the morphology of cells and significantly increased cellular activity. In conclusion, our data demonstrate the stimulating effect of steroid drugs on cell morphology, proliferation rate and cytophysiological activity. These findings may influence the use of stem cells and steroids in applied regenerative veterinary medical practice in the future.
\end{abstract}

Key words: Adipose-derived mesenchymal stem cells (AdMSCs), canine, equine, cell therapies, corticosteroids

In the veterinary practice, locomotive system disorders affecting dogs and horses are the most commonly occurring therapeutic problem. The major risk factors of these diseases include sports-related and traumatic injuries, but these conditions are also enhanced by aging and/or genetic factors. The number of

\footnotetext{
*Corresponding author; E-mail: grzesiak.kuba@gmail.com; Phone: 0048 (71) 3205-888
} 
animals suffering from degenerative joint diseases (DJDs) steadily increases from year to year. The National Animal Health Monitoring Systems Programme declared that more than $20 \%$ of all dogs have been diagnosed with osteoarthritis $(\mathrm{OA})$ in the United States alone. Moreover, approximately $60 \%$ of equine lameness cases are related to osteoarthritis (Caron and Genovese, 2003; Black et al., 2007; Egenvall et al., 2010). Degenerative joint disorders impair animal welfare and thus require long-term veterinary care. These disorders not only restrict animals in their physiological activities, but in severe cases may lead to euthanasia (Butt, 2002; Black et al., 2008).

Degeneration and erosion of articular cartilage are triggered by inflammation factors such as cytokines, free radicals, metalloproteinases or prostaglandins. The predominance of catabolic processes over anabolic ones leads to the loss of tissue homeostasis. The prolonged activity of inflammatory mediators results in cartilage disintegration and causes joint degeneration manifesting itself in chronic lameness (Carter et al., 1999; De Grauw et al., 2009).

To reduce the trauma arising from articular cartilage degeneration, the routine veterinary treatment usually involves the application of steroid drugs. They are commonly used in pain management because of their anti-inflammatory properties. The general effect of steroids involves the inhibition of actions of pivotal proinflammatory cytokines, enzymes, receptors and adhesion molecules (Barnes, 1998; Goodrich and Nixon, 2006; Holloway et al., 2012). The most widely used steroids are synthetic glucocorticoids, mainly methylprednisolone (depo-medrol) and betamethasone. Their use, along with that of nonsteroidal anti-inflammatory drugs (NSAIDs), is still the primary therapy of choice (Sanderson et al., 2009; Mcllwraith, 2010). However, it is well known that prolonged steroid treatment leads to many dangerous side effects, such as the well-known Cushing's syndrome, muscle wasting, hyperglycaemia, gastropathy, hepatopathy, immunosuppression, polydypsia, polyuria or water retention (Llewellyn, 2002). However, there are some reports suggesting positive effects of steroid therapy, e.g. increased testosterone level in cover stallions or an elevated number of red blood cells. In locomotive system disorders, the influence of steroids is limited to pain reduction and delay of disease progress. Therefore, the patients' condition improves only seemingly and usually temporarily. Sufficient and effective therapies should focus not only on the clinical signs but, most of all, on the regeneration of damaged tissue to restore its proper physiological functions. It has to be stressed that the objective of regenerative medicine is to alter the development of disease, parallel with pain reduction. This approach is found to be the main goal in regenerative medicine for small and large animals (Black et al., 2007; Hodgkiss-Geere et al., 2012).

Auto-transplantation of stem cells is regarded as cutting edge in pain management. The last decade brought novel strategies for DJD and OA treatment using stem cell injections. Many research groups have shown that transplantations 
of adult stem cells bring positive clinical outcomes. New populations of adult stem cells are still being discovered. However, it seems that adipose-derived stem cells (AdMSCs), together with those of bone marrow origin, play a primary role in veterinary clinical treatment, both in small and large animals (Gattegno-Ho et al., 2012; Burk et al., 2013; Hackett, 2013). In veterinary regenerative medicine, stem cell therapies are becoming more and more available, e.g. in the regeneration of skeletal muscle and tendon injuries (Puissant et al., 2005; Del Bue et al., 2008; Brown et al., 2012; Lin et al., 2012). The use of AdMSCs in veterinary practice is supported not only by their multipotent character and plasticity, but also by their immunomodulatory properties, manifested in the reduction of inflammatory processes. It was already proven that applications of AdMSCs significantly decrease the concentration of proinflammatory cytokines at the wound site, which is reflected in pain and trauma relief (Gonzalez et al., 2009).

The regenerative potential of mesenchymal stem cells can be assessed by several, particular parameters, including the evaluation of morphology and ultrastructure; it is, however, often neglected by many researchers. Analysis of these parameters, in terms of cell transplantations, provides the selection of cells with the highest proliferative potential, which reflects on the regenerative capability of the transplant at further stages of therapy (Dimitrieva et al., 2012; Vishnubalaji et al., 2012). The size and localisation of nuclei, as well as cellular composition, are the basic parameters for determining cell condition. Another important issue is the analysis of the cellular physiological activity of MSCs. This feature can be determined by the evaluation of the localisation, size and density of microvesicles (MVs). As it was reported previously, MVs shed by adult stem cells are rich in a broad range of growth factors and cytokines, e.g. Vascular Endothelial Growth Factor (VEGF), Fibroblast Growth Factor (FGF), Monocyte Chemoattractant Protein-1 (MCF-1), Hepatocyte Growth Factor (HGF), Insulin-like Growth Factor 1 (IGF-1) and Bone Morphogenetic Proteins (BMP), which exert effects on cells in their vicinity (Lai et al., 2011). Moreover, the presence of structures such as cytonemes and tunneling nanotubes also indicates improved cell activity and may correlate with the natural proliferation activity of MSCs (Yasuda et al., 2011; Lou et al., 2012).

The goal of this research was to analyse the influence of commonly used steroid drugs, namely methylprednisolone and betamethasone, on equine and canine AdMSC under culture conditions. The morphology and the viability of the selected cells were determined. Moreover, based on the amount and localisation of microvesicles, the cytophysiological activity of cultured cells was studied. 


\section{Materials and methods}

\section{Isolation of AdMSCs}

Mesenchymal stem cells were isolated from subcutaneous fat tissue from dogs and horses. This work did not need the approval of the Local Bioethics Committee, as the work on animal cells and tissues is not considered an experiment on animals. All stages of the procedure were performed as previously described (Grzesiak et al., 2011a,b). Briefly, fat tissue biopsies were washed in Hank's Balanced Salt Solution (HBSS, Sigma) to remove blood contaminations, and then minced and digested in type I collagenase $(5 \mathrm{mg} / \mathrm{ml})$. To ensure effective digestion of the tissue samples, fragments were transferred to a $\mathrm{CO}_{2}$ incubator at $37{ }^{\circ} \mathrm{C}$ for $40 \mathrm{~min}$. Subsequently, samples were centrifuged at $1200 \times \mathrm{g}$ for $10 \mathrm{~min}$. After centrifugation, the supernatant with floating adipocytes was discarded and the cell pellet with stromal vascular fraction (SVF) was suspended in culture media and plated into culture dishes. After $24 \mathrm{~h}$, the medium was changed to remove non-adherent cells. Ham's F12 medium was used for primary culture and DMEM with $4500 \mathrm{mg} / \mathrm{L}$ of glucose for secondary culture. The media were supplemented with $10 \%$ of fetal bovine serum (FBS) and with $1 \%$ of antibiotic/ antimycotic solution (all from Sigma). For normal growth, cultures were kept in incubator $\left(5 \% \mathrm{CO}_{2}, 95 \%\right.$ humidity, at $\left.37^{\circ} \mathrm{C}\right)$ and the medium was changed every two days on average. The cells were passaged at the same time, before running the tests with steroids.

\section{Steroids}

Methylprednisolone (depo-medrol, Pfizer) and betamethasone (ScheringPlough) were tested in vitro at concentrations of $0.01 \mathrm{mg} / \mathrm{ml}, 0.1 \mathrm{mg} / \mathrm{ml}$ and $1.0 \mathrm{mg} / \mathrm{ml}$.

In vitro evaluation of the effect of steroids on AdMSCs

Cells were seeded into 24 -well plates at a density of 20,000 per well. Stimulation with the drugs started after 6 h, i.e. when cell adhesion and spreading into the plate surface were noticed. Untreated cells provided a reference point for comparing the samples tested. All specimens were prepared in duplicates. The medium was changed $48 \mathrm{~h}$ after the cells' propagation. Morphology and viability of the cells were evaluated after 24,72 and $120 \mathrm{~h}$, with regard to the results reported by Nuzzi et al. (2012).

\section{Cytotoxicity test}

The degree of cytotoxicity induced by the drugs was assessed by evaluation of metabolic activity of living cells using the resazurin-resorufin system (Alamar Blue, Sigma). Dye solution was added in an amount equal to $10 \%$ of the 
culture medium volume. Cells were incubated with the dye for $2 \mathrm{~h}$ in a $\mathrm{CO}_{2}$ incubator. After this time, supernatants were collected and measured spectrophotometrically by monitoring the decrease in absorbance at a wavelength of $600 \mathrm{~nm}$ with a reference wavelength of $690 \mathrm{~nm}$, by means of a microplate reader (Spectrostar Nano, BMG Labtech). Each test included a blank containing complete medium without cells. To evaluate the proliferation rate, a standard curve of a different range of cell concentrations $\left(2 \times 10^{4}, 4 \times 10^{4}, 8 \times 10^{4}\right.$ and $\left.16 \times 10^{4}\right)$ with an absorbance directly proportional to the cell number, was constructed.

\section{Evaluation of cell morphology and activity}

The morphology of cells was evaluated both in the culture with drugs and in the control culture with untreated cells. Cell morphology was evaluated under inverted phase contrast microscope, epifluorescent microscope (Zeiss, Axio Observer A.1) and using scanning electron microscopy (SEM, Zeiss Evo LS 15).

For the analysis of cellular composition, diamidino-2-phenylindole (DAPI) was used for the staining of nuclei and phalloidin for the visualisation of actin filaments. Prior to staining, the cells were fixed with $4 \%$ ice-cold paraformaldehyde for $15 \mathrm{~min}$ at room temperature. After fixation, cells were washed and permeabilised with $0.1 \%$ Triton X-100 for $15 \mathrm{~min}$ at room temperature. Cells were washed again, stained with atto-488-labelled phalloidin for $30 \mathrm{~min}$ and counterstained with DAPI for $5 \mathrm{~min}$. After staining, samples were washed three times and observed in an inverted, epifluorescence microscope.

For scanning electron microscopy, the cells were fixed in $2.5 \%$ glutaraldehyde (1:1 in DMEM) for $30 \mathrm{~min}$ at room temperature, then washed three times with phosphate-buffered saline (PBS) and dehydrated in an ascending ethanol series (grades of $10 \%$ from $50 \%$ to $100 \%$ ). Cells were observed with an SE1 detector, at $10 \mathrm{kV}$ of filament tension.

\section{Results}

\section{Cytotoxicity test}

Betamethasone showed slight or no toxic effect on canine and equine AdMSCs on the first and second days of the test. Nevertheless, after five days of canine AdMSC culture, the proliferation rates were approximately $50 \%$ lower than those obtained on the second day. However, on the fifth day of the experiment, different observations were made for equine AdMSC culture, where the addition of betamethasone in a concentration of 0.01 and $0.1 \mathrm{mg} / \mathrm{ml}$, respectively, enhanced the cells' proliferation or maintained it on the same level as in the control culture. Inhibition of proliferation was observed on the fifth day in cultures where the highest betamethasone concentration was applied (Figs 1 and 3). 


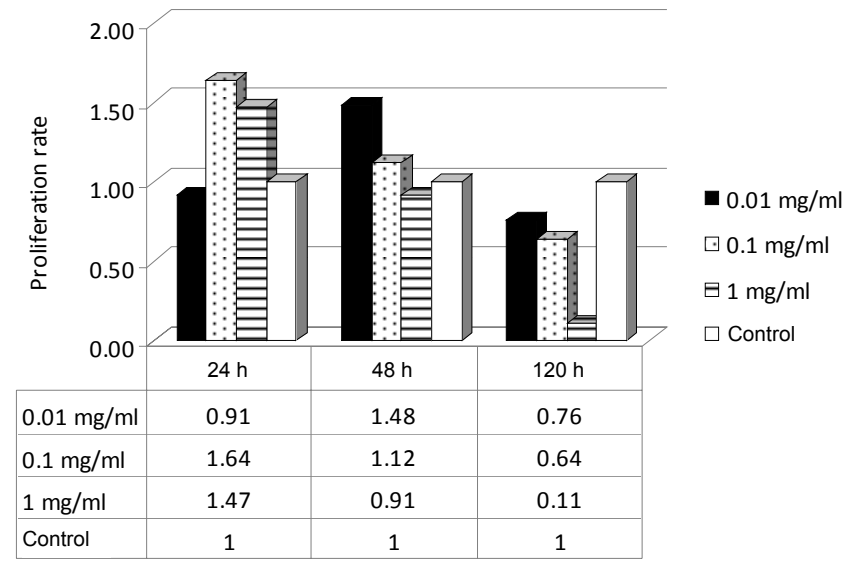

Fig. 1. Proliferation rates of canine AdMSC in the presence of betamethasone at different concentrations

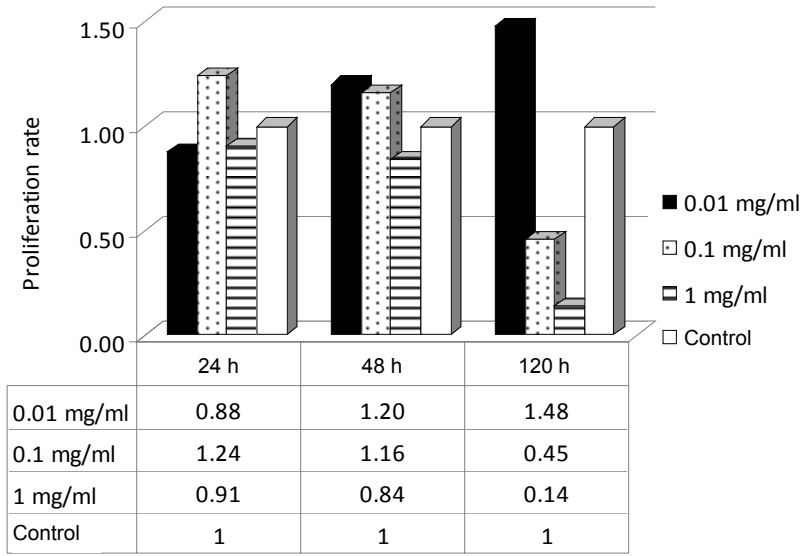

Fig. 2. Proliferation rates of canine AdMSC in the presence of methylprednisolone (depo-medrol) at different concentrations

Methylprednisolone, when applied at the lowest concentration $(0.01 \mathrm{mg} / \mathrm{ml})$, exerted a stimulating effect on canine and equine AdMSCs during the entire course of culture. Addition of methylprednisolone in $0.1 \mathrm{mg} / \mathrm{ml}$ concentration maintained or enhanced the proliferative activity of cells only after 24 and $48 \mathrm{~h}$ of propagation, whereas the proliferation of AdMSCs was significantly lowered after $120 \mathrm{~h}$. The highest concentration of methylprednisolone had strong cytotoxic effect on AdMSCs, which was particularly visible on the last day of measurement (Figs 2 and 4).

It is worth noting that the cultures of equine AdMSCs, treated with different concentrations of the steroids tested, were re-established at the second day of 
propagation. This was manifested in higher proliferation rates obtained after $48 \mathrm{~h}$ in comparison to those obtained after $24 \mathrm{~h}$ (Figs 2 and 4). Regarding the culture of canine AdMSCs, this phenomenon was observed only when a steroid concentration of $0.01 \mathrm{mg} / \mathrm{ml}$ was applied (Figs 1 and 3).

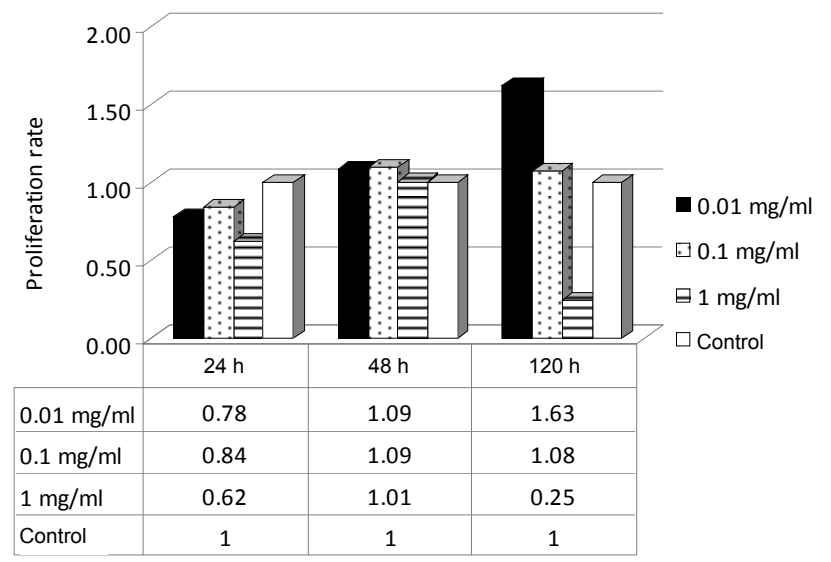

Fig. 3. Proliferation rates of equine AdMSCs in the presence of betamethasone at different concentrations

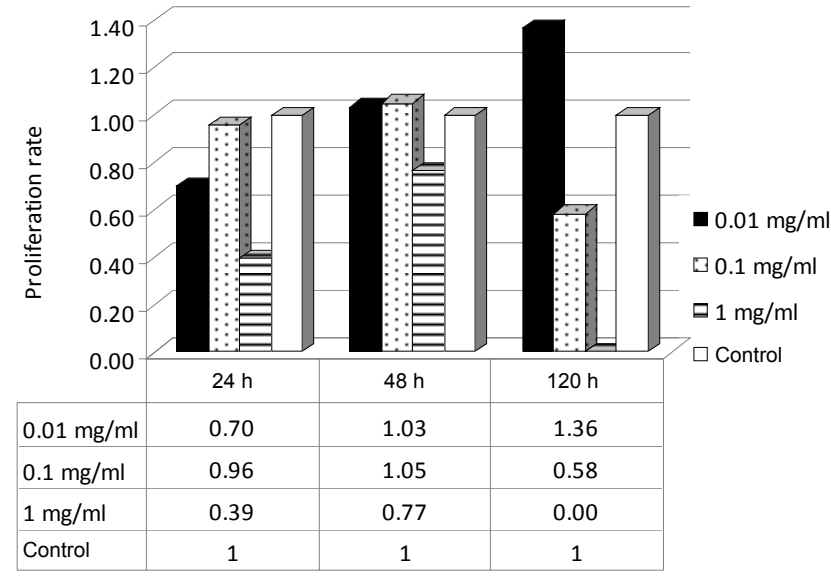

Fig. 4. Proliferation rates of canine AdMSC in the presence of methylprednisolone (depo-medrol) at different concentrations

Morphology and cell activity of canine and equine AdMSCs

Neither of the two drugs, when used at concentrations of 0.01 and $0.1 \mathrm{mg} / \mathrm{ml}$, affected the morphology of cells during the entire course of culture. This situation was similar in all combinations, with the exception of the culture of equine 
AdMSCs with methylprednisolone. In this case, after five-day propagation, both concentrations of drugs caused abnormal culture growth pattern and the formation of apoptotic bodies (Figs 5-8).
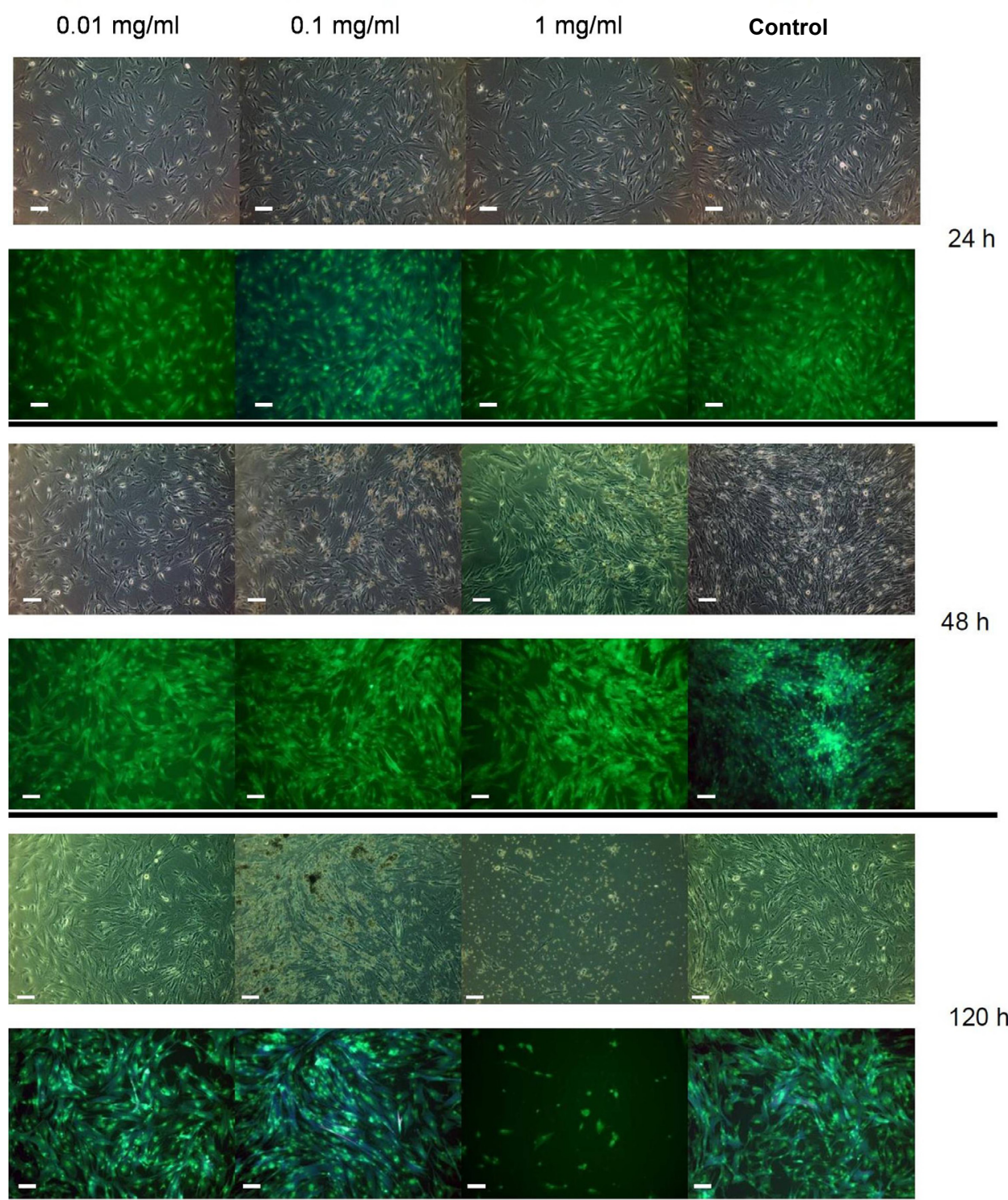

Fig. 5. Morphological analysis of canine AdMSC culture in the presence and absence of betamethasone. Scale bar $=125 \mu \mathrm{m}$ 

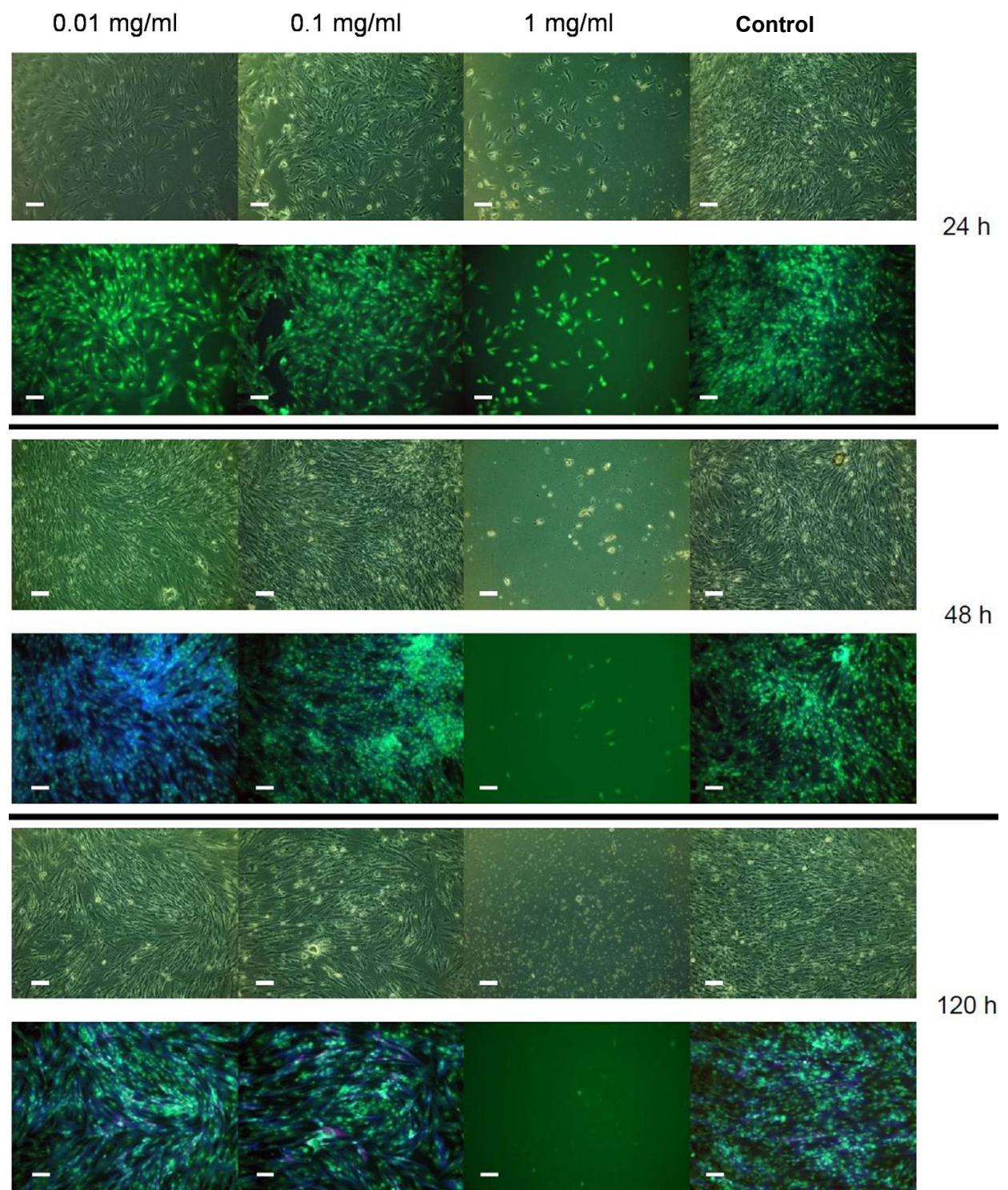

$120 \mathrm{~h}$

Fig. 6. Morphological analysis of canine AdMSC culture in the presence and absence of methylprednisolone (depo-medrol). Scale bar $=125 \mu \mathrm{m}$

The highest dosage of drugs used in the research $(1 \mathrm{mg} / \mathrm{ml})$ induced morphological changes in the cells and promoted the development of apoptotic bodies. In cultures of canine AdMSCs, the highest dosage of betamethasone caused cell death on the fifth day of propagation, while methylprednisolone already on the second day (Figs 5 and 6). Regarding the equine cultures, the presence of $1 \mathrm{mg} / \mathrm{ml}$ 
betamethasone did not induce death of the whole cell population but only significantly reduced the number of cells on the fifth day of experiment. Methylprednisolone exerted a toxic effect on equine AdMSCs, which was particularly evident after 5 days of culture (Figs 7 and 8 ).
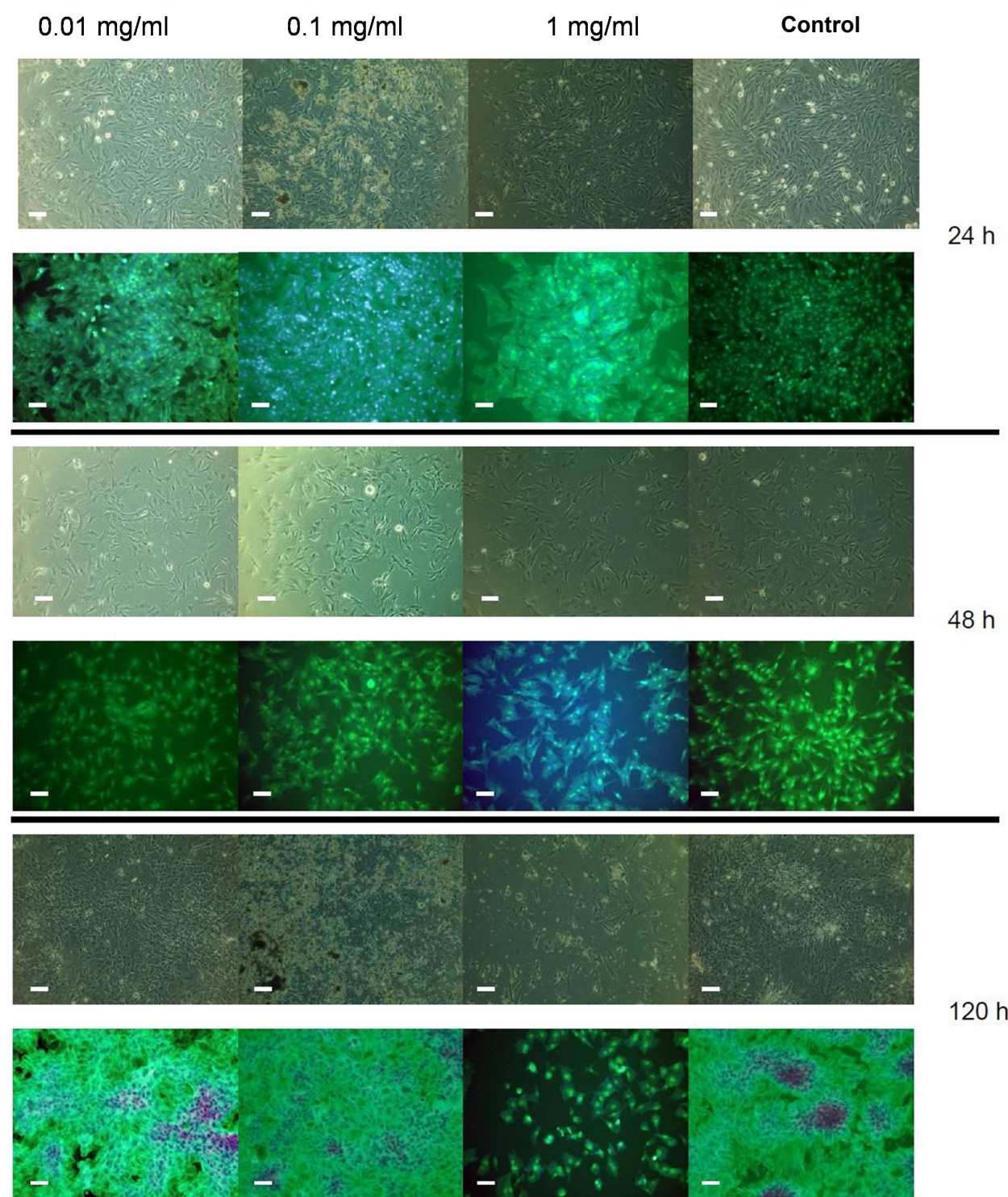

Fig. 7. Morphological analysis of equine AdMSC culture in the presence and absence of betamethasone. Scale bar $=125 \mu \mathrm{m}$ 

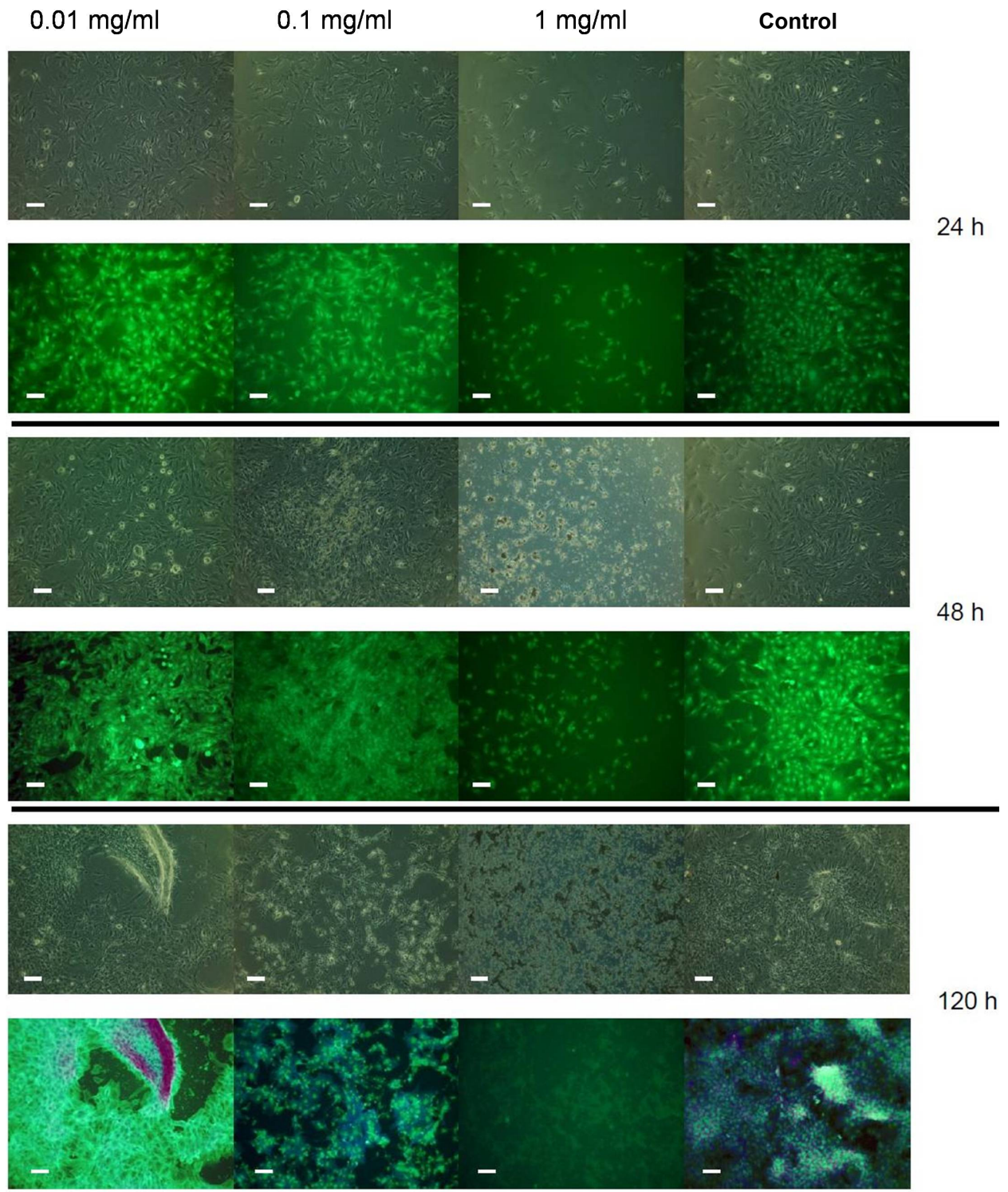

Fig. 8. Morphological analysis of equine AdMSC culture in the presence and absence of methylprednisolone (depo-medrol). Scale bar $=125 \mu \mathrm{m}$

The evaluation of cell activity expressed by the synthesis of microvesicles showed that the lowest concentration $(0.01 \mathrm{mg} / \mathrm{ml})$ of both drugs stimulated canine and equine AdMSCs. This effect was maintained throughout the entire course of culture (Figs 9-10). The increased presence of MVs was observed in all cases, always after $24 \mathrm{~h}$ of cell culture. However, the addition of methylpred- 
nisolone and betamethasone in the highest concentration was accompanied by changes in cytoplasm organisation, manifested in the formation of a foamy structure.

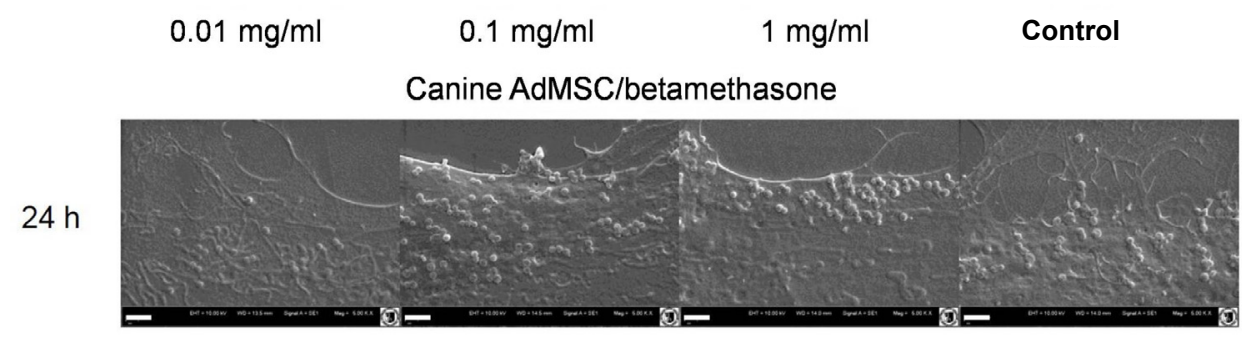

$48 \mathrm{~h}$

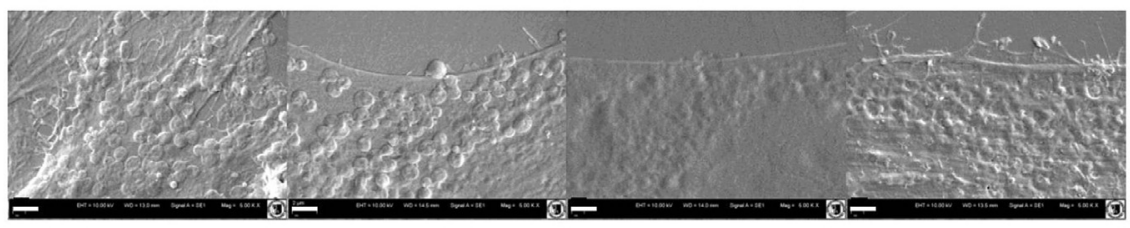

$120 \mathrm{~h}$
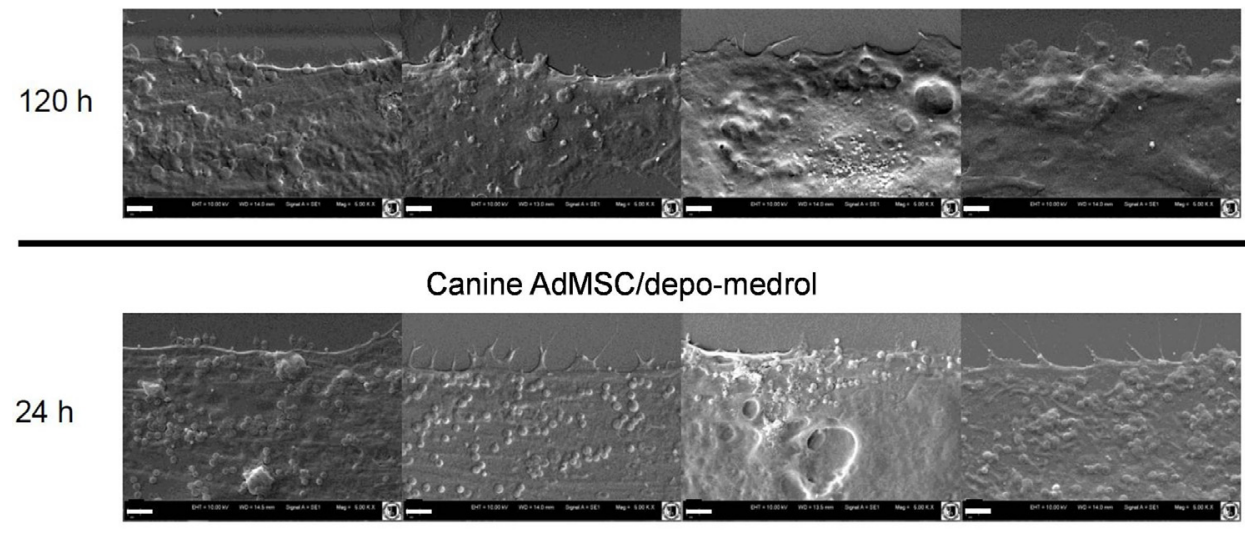

$48 \mathrm{~h}$

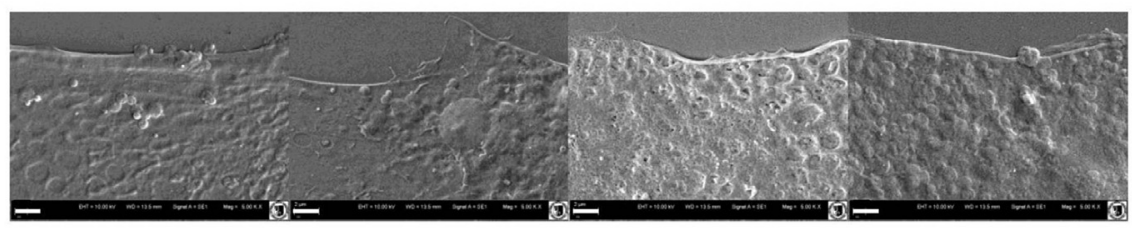

$120 \mathrm{~h}$

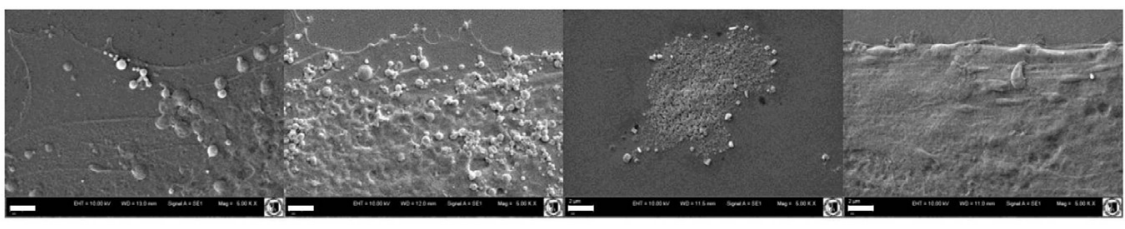

Fig. 9. Microvesicles shed from canine AdMSCs at different concentrations of betamethasone and methylprednisolone (depo-medrol). Scale bar $=2 \mu \mathrm{m}$ 


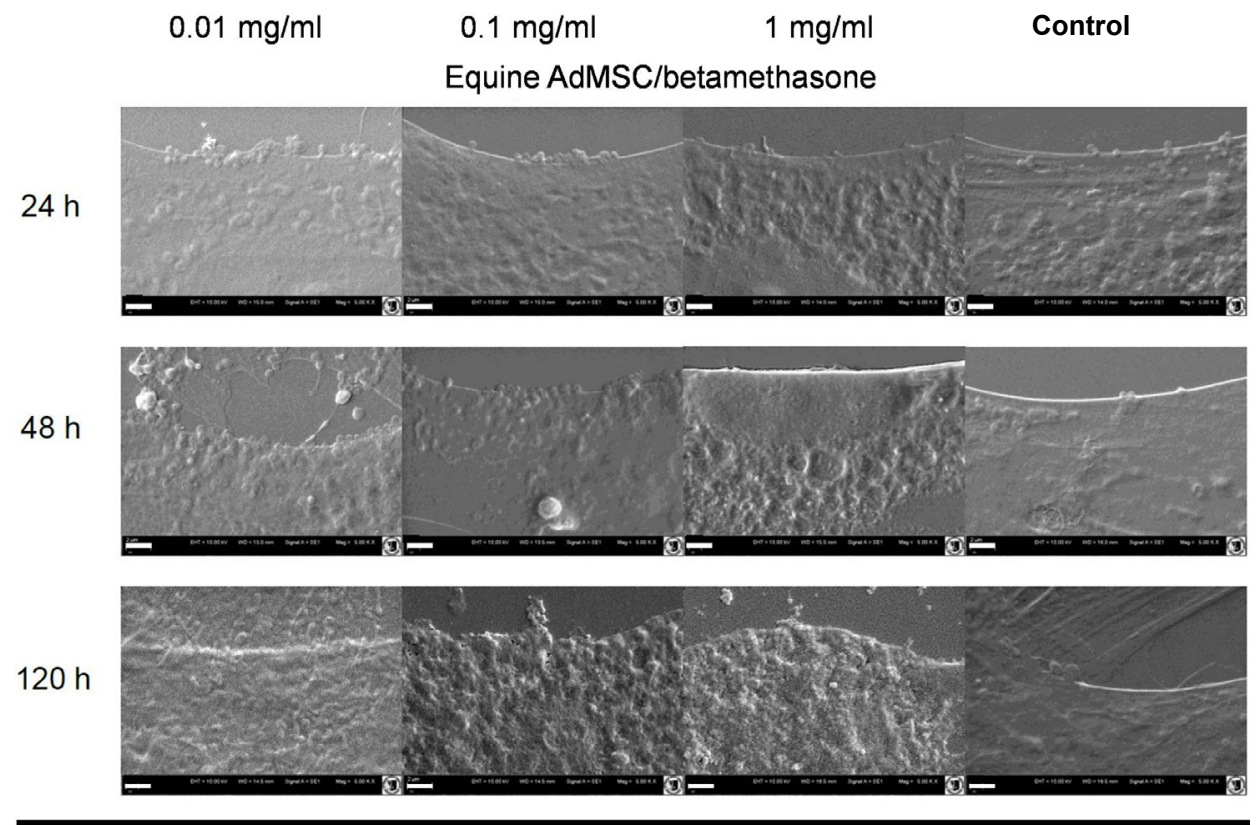

Equine AdMSC/depo-medrol

$24 \mathrm{~h}$

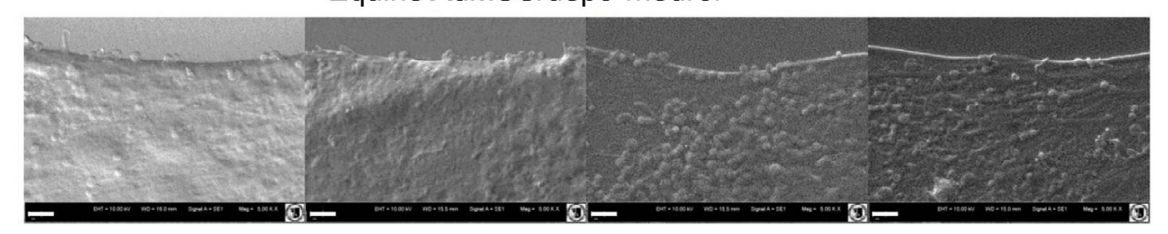

$48 \mathrm{~h}$

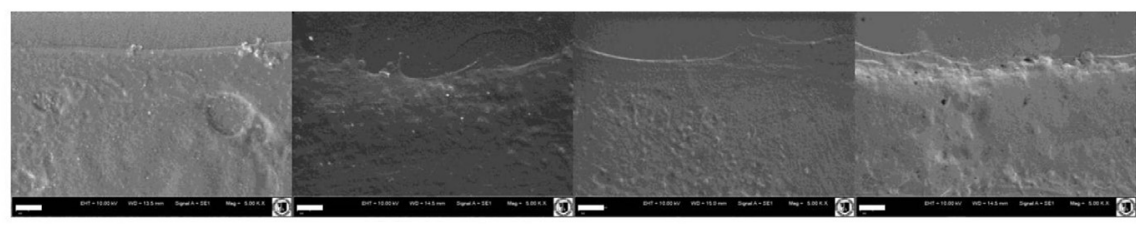

$120 \mathrm{~h}$

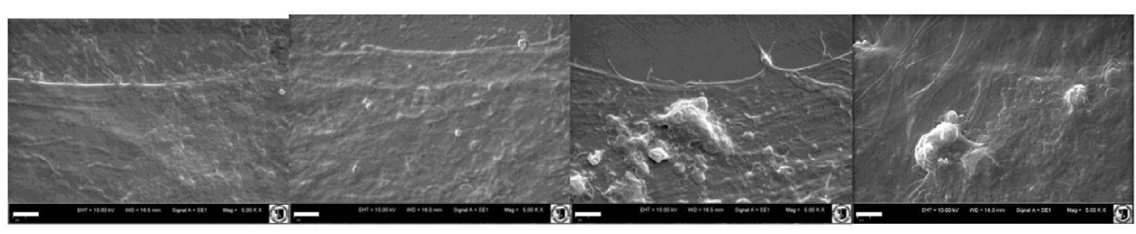

Fig. 10. Microvesicles shed from equine AdMSCs at different concentrations of betamethasone and methylprednisolone (depo-medrol). Scale bar $=2 \mu \mathrm{m}$ 


\section{Discussion}

The incidence of locomotive system disorders is increasing rapidly in both small and large animals. Degenerative joint disorders cause lameness, reduce the range of motion and contribute to the patients' suffering. The gold standard in DJD treatment is steroid therapy, which reduces the pain level but only in the short term and usually without significantly changing the long-term clinical picture. Therapeutic procedures using steroid injections are commonly available and applicable; however, all groups of clinicians have observed side effects as a result of prolonged steroid usage. Despite the fact that steroid therapies are associated with adverse reactions, they have been the main treatment modality for DJD for over thirty years (Supance, 1983; Carter et al., 1999).

The discovery of adult stem cells has offered an alternative therapeutic approach (Black et al., 2007). As was reported by Zuk et al. (2002), stem cells can be easily obtained from adult tissues and differentiated in vitro into various lineages. Successful outcomes were noticed after injections of adult mesenchymal stem cells of different origin. Regeneration of degenerative tissue using stem cells injections is still a novel advance in modern veterinary practice. This approach focuses on restoring the physiological function of tissues, simultaneously with pain relief. The process of tissue regeneration is complex, and still has to be investigated in detail (Hackett, 2013). An important observation is that AdMSCs possess immunomodulatory properties, especially the ability to secrete antiinflammatory factors. Therefore, as tissue heals, pain relief is also prominent. Moreover, pain reduction that results from the action of injected cells occurs after a certain period of time, but not immediately. In contrast, the application of steroids provides significant and immediate pain reduction, but this effect wanes after a relatively short time, two to three weeks (Coleman et al., 2010; Qui et al., 2012).

We assumed that the combination of stem cells and steroid drugs in specific proportions may not only provide an immediate pain-relieving effect but could also lead to an efficient regeneration of damaged tissue. Our results suggest that steroids affect the viability and proliferation rate of cells in both canine and equine cell cultures. We observed that at concentrations of $0.01 \mathrm{mg} / \mathrm{ml}$ and $0.1 \mathrm{mg} / \mathrm{ml}$ both steroid drugs exerted a stimulating effect on the proliferation and viability of both equine and canine AdMSCs and, moreover, they did not affect the morphology of cells. The stimulated stem cells showed proper, fibroblastic shape with big and eccentrically located nuclei.

While the lowest concentrations had a favourable influence on cell cultures, stimulating them to higher proliferation, the concentration of $1 \mathrm{mg} / \mathrm{ml} \mathrm{had}$ a cytotoxic effect, which was particularly evident on the fifth day of culture, when a rapid decrease of proliferation rate and cell death were noticed. These findings correlate with the results of Nuzzi et al. (2012); however the experimental model of the latter research group was based on the use of human bone mar- 
row mesenchymal stem cells (hBMSC). Therefore, it seems that a diverse population of MSCs isolated from different species reacts similarly to the same group and concentration of steroid drugs. Comparing the effects of the two steroids studied in this experiment, betamethasone was less toxic to equine cells and methylprednisolone to canine cells.

On the basis of the results obtained, we presume that the physical properties of steroid drugs should also be taken into consideration. The drug particles present in the cultures could have been an obstacle to cellular adhesion, movement and proliferation, and consequently it could have been partially responsible for the observed negative effects of the drugs. Our results demonstrated that steroids promote the proliferation of AdMSCs. In cases where cells were stimulated with drug concentrations of 0.01 and $0.1 \mathrm{mg} / \mathrm{ml}$, we observed not only higher proliferation rate but also intensified activity of the cells. This was manifested in the number of produced MVs and the formation of specific cellular structures, namely cytonemes and tunneling nanotubes. Based on common knowledge, we assume that the presence of microvesicles at the wound site could reflect the proregenerative potential of stem cells. As it was demonstrated, MVs rich in numerous bioactive factors play a crucial role in cell paracrine and autocrine signalling (Ratajczak et al., 2006a, b).

On the basis of the results obtained, in order to reduce the pain and to improve the regeneration of tissue damaged due to DJD, it seems to be reasonable to combine stem cell therapy and steroid drugs in particular proportions. Finally, for the further clinical application of this therapeutic approach, in vivo studies are crucial to better understand the complexity of regeneration mechanisms. We presume that in-depth analysis of the impact of steroid drugs on the biology of MSCs will open up new areas of eventual therapeutic strategies. If these conclusions are confirmed by clinical trials, this will result in the elaboration of improved stem cell therapies for DJD.

\section{Acknowledgement}

We would like to thank MSc Krzysztof Kaliński for technical support.

\section{References}

Barnes, P. J. (1998): Anti-inflammatory actions of glucocorticoids: molecular mechanisms. Clin. Sci. 94, 557-572.

Black, L. L., Gaynor, J., Gahring, D., Adams, C., Aron, D., Harman, S., Gingerich, D. A. and Harman, R. (2007): Effect of adipose-derived mesenchymal stem and regenerative cells on lameness in dogs with chronic osteoarthritis of the coxofemoral joints: a randomized, double-blinded, multicenter, controlled trial. Vet. Ther. 8, 272-284.

Black, L. L., Gaynor, J. J., Adams, C., Dhupa, S., Sams, D. E., Taylor, R., Harman, S., Ginderich, D. A. and Harman, R. (2008): Effect of intraarticular injection of autologous adipose- 
derived mesenchymal stem and regenerative cells on clinical signs of chronic osteoarthritis of the elbow joint in dogs. Vet. Ther. 9, 192-200.

Brown, S. G., Harman, R. J. and Black, L. L. (2012): Adipose-derived stem cell therapy for severe muscle tears in working German shepherds: Two case reports. Stem Cell Discov. 2, 41-44.

Burk, J., Ribitsch, I., Gittel, C., Juelke, H., Kasper, C., Staszyk, C. and Brehm, W. (2013): Growth and differentiation characteristics of equine mesenchymal stromal cells derived from different sources. Vet. J. 195, 98-106.

Butt, T. (2002): Septic arthritis in horses: diagnosis and treatment. Large Anim. Vet. Rounds 2, 1-6.

Caron, J. P. and Genovese, R. L. (2003): Principles and practices of joint disease treatment. In: Ross, M. W. and Dyson, S. J. (eds) Diagnostics and Management of Lameness in the Horse. Elsevier, Amsterdam. pp. 746-763.

Carter, S. D., Barnes, A. and Gilmore, W. H. (1999): Canine rheumatoid arthritis and inflammatory cytokines. Vet. Immunol. Immunopathol. 69, 201-214.

Coleman, C. M., Curtin, C., Barry, F. P., O’Flatharta, C. and Murphy, J. M. (2010): Mesenchymal stem cells and osteoarthritis: remedy or accomplice? Hum. Gene Ther. 21, 1239-1250.

De Grauw, J. C., van de Lest, C. H. and van Weeren, P. R. (2009): Inflammatory mediators and cartilage biomarkers in synovial fluid after a single inflammatory insult: a longitudinal experimental study. Arthritis Res. Ther. 11, R35.

Del Bue, M., Riccò, S., Ramoni, R., Conti, V., Gnudi, G. and Grolli, S. (2008): Equine adiposetissue derived mesenchymal stem cells and platelet concentrates: their association in vitro and in vivo. Vet. Res. Commun. 32, S51-S55.

Dimitrieva, R. I., Minullina, I. R., Bilibina, A. A., Tarasova, O. V., Anisimov, S. V. and Zaritskey, A. Y. (2012): Bone marrow- and subcutaneous adipose tissue-derived mesenchymal stem cells: differences and similarities. Cell Cycle 11, 377-383.

Egenvall, A., Lönnell, C., Johnston, C. and Roepstorff, L. (2010): Orthopaedic health status of horses from 8 riding schools - a pilot study. Acta Vet. Scand. 52, 2-8.

Gattegno-Ho, D., Argyle, S. A. and Argyle, D. J. (2012): Stem cells and veterinary medicine: tools to understand diseases and enable tissue regeneration and drug discovery. Vet. J. 191, 19-27.

Gonzalez, M. A., Gonzalez-Rey, E., Rico, L., Buscher, D. and Delgado, M. (2009): Adiposederived mesenchymal stem cells alleviate experimental colitis by inhibiting inflammatory and autoimmune responses. Gastroenterology 136, 978-989.

Goodrich, L. R. and Nixon, A. J. (2006): Medical treatment of osteoarthritis in the horse - a review. Vet. J. 171, 51-69.

Grzesiak, J., Marycz, K., Czogala, J., Wrzeszcz, K. and Nicpoń, J. (2011a): Comparison of behavior, morphology and morphometry of equine and canine adipose derived mesenchymal stem cells in culture. Int. J. Morphol. 29, 1012-1017.

Grzesiak, J., Marycz, K., Wrzeszcz, K. and Czogała, J. (2011b): Isolation and morphological characterisation of ovine adipose-derived mesenchymal stem cells in culture. Int. J. Stem Cells 4, 99-104.

Hackett, C. H. (2013): Assessing the function of mesenchymal stromal cells: all that glitters is not gold. Vet. J. 195, 10-11.

Hodgkiss-Geere, H. M., Argyle, D. J., Corcoran, B. M., Whitelaw, B., Milne, E., Bennett, D. and Argyle, S. A. (2012): Characterisation and differentiation potential of bone marrow derived canine mesenchymal stem cells. Vet. J. 194, 361-368.

Holloway, H., Robinson, A. and Mailand, T. P. (2012): Benefits of continuous long-term treatment of canine degenerative joint disease with carprofen. Rev. Méd. Vét. 163, 95-104.

Lai, R. C., Chen, T. S. and Lim, S. K. (2011): Mesenchymal stem cell exosome: a novel stem cellbased therapy for cardiovascular disease. Regen. Med. 6, 481-492.

Lin, C. S., Lin, G. and Lue, T. F. (2012): Allogeneic and xenogeneic transplantation of adiposederived stem cells in immunocompetent recipients without immunosuppressants. Stem Cells Dev. 21, 2770-2778.

Llewellyn, M. (2002): Cushing's disease threatens the health of the older horse. Equinews 5, 14-17. 
Lou, E., Fujisawa, S., Barlas, A., Romin, Y., Manova-Todorova, K., Moore, M. A. and Subramanian, S. (2012): Tunneling nanotubes: A new paradigm for studying intercellular communication and therapeutics in cancer. Commun. Integr. Biol. 5, 399-403.

McIlwraith, C. W. (2010): Management of joint disease in the sport horse. 17th Kentucky Equine Research Nutrition Conference, Lexington, Kentucky, USA.

Nuzzi, R., Gunetti, M., Rustichelli, D., Roagna, B., Fronticelli Bardelli, F., Fagioli, F. and Ferrero, I. (2012): Effect of in vitro exposure of corticosteroid drugs, conventionally used in AMD treatment, on mesenchymal stem cells. Stem Cells Int., Article ID 946090.

Puissant, B., Barreau, C., Bourin, P., Clavel, C., Corre, J., Bousquet, C., Taureau, C., Cousin, B., Abbal, M., Laharrague, P., Penicaud, L., Casteilla, L. and Blancher, A. (2005): Immunomodulatory effect of human adipose tissue-derived adult stem cells: comparison with bone marrow mesenchymal stem cells. Brit. J. Haematol. 129, 118-129.

Qui, Y., Feng, G. and Yan, W. (2012): Mesenchymal stem cell-based treatment for cartilage defects in osteoarthritis. Mol. Biol. Rep. 39, 5683-5689.

Ratajczak, J., Miekus, K., Kucia, M., Zhang, J., Reca, R., Dvorak, P. and Ratajczak, M. Z. (2006a): Embryonic stem cell-derived microvesicles reprogram hematopoietic progenitors: evidence for horizontal transfer of mRNA and protein delivery. Leukemia 20, 847-856.

Ratajczak, J., Wysoczynski, M., Hayek, F., Janowska-Wieczorek, A. and Ratajczak, M. Z. (2006b): Membrane-derived microvesicles: important and underappreciated mediators of cell-to-cell communication. Leukemia 20, 1487-1495.

Sanderson, R. O., Beata, C., Flipo, R. M., Genevois, J. P., Macias, C., Tacke, S., Vezzoni, A. and Innes, J. F. (2009): Systematic review of the management of canine osteoarthritis. Vet. Rec. 164, 418-424.

Supance, J. S. (1983): Antibiotics and steroids in the treatment of acquired subglottic stenosis. A canine model study. Ann. Otol. Rhinol. Laryngol. 92, 377-382.

Vishnubalaji, R., Al-Nbaheen, M., Kadalmani, B., Aldahmash, A. and Ramesh, T. (2012): Comparative investigation of the differentiation capability of bone-marrow- and adiposederived mesenchymal stem cells by qualitative and quantitative analysis. Cell Tissue Res. 347, 419-427.

Yasuda, K., Khandare, A., Burianovskyy, L., Maruyama, S., Zhang, F., Nasjletti, A. and Goligorsky, M. S. (2011): Tunneling nanotubes mediate rescue of prematurely senescent endothelial cells by endothelial progenitors: exchange of lysosomal pool. Aging 3, 597-608.

Zuk, P. A., Zhu, M., Ashjian, P., De Ugarte, D. A., Huang, J. I., Mizuno, H., Alfonso, Z. C., Fraser, J. K., Benhaim, P. and Hedrick, M. H. (2002): Human adipose tissue is a source of multipotent stem cells. Mol. Biol. Cell 13, 4279-4295. 